\title{
Increased expression of SUMO1P3 predicts poor prognosis and promotes tumor growth and metastasis in bladder cancer
}

\author{
Yonghao Zhan ${ }^{1,2,3, *}$, Yuchen Liu'1,2,*, Chaoliang Wang ${ }^{4, *}$, Junhao Lin ${ }^{1,3}$, Mingwei \\ Chen $^{1}$, Xiaoying Chen ${ }^{1,3}$, Chengle Zhuang ${ }^{1,3}$, Li Liu ${ }^{1,3}$, Wen X ${ }^{1}{ }^{1}$, Qing Zhou ${ }^{1}$, Xiaojuan \\ Sun ${ }^{1}$, Qiaoxia Zhang ${ }^{1}$, Guoping Zhao ${ }^{1,5}$, Weiren Huang ${ }^{1,2,3}$ \\ ${ }^{1}$ Key Laboratory of Medical Reprogramming Technology, Shenzhen Second People's Hospital, The First Affiliated Hospital of \\ Shenzhen University, Shenzhen, China \\ ${ }^{2}$ Department of Urology, Peking University First Hospital, Institute of Urology, Peking University, National Urological Cancer \\ Centre, Beijing, China \\ ${ }^{3}$ Shantou University Medical College, Shantou, China \\ ${ }^{4}$ Urology Department, The First Affiliated Hospital of Zhengzhou University, Zhengzhou, China \\ ${ }^{5}$ Shanghai-MOST Key Laboratory of Health and Disease Genomics, Chinese National Human Genome Centerat Shanghai, \\ Shanghai, China \\ *These authors have contributed equally to this work
}

Correspondence to: Weiren Huang, e-mail: pony8980@163.com

Keywords: SUMO IP3, bladder cancer, tumor growth, tumor metastasis

Received: October 01,2015 Accepted: January 02, $2016 \quad$ Published: January 19, 2016

\section{ABSTRACT}

Bladder cancer is one of the most common malignancies worldwide. Long noncoding RNAs (IncRNAs) are a class of non-coding RNAs that play crucial roles in diverse biological processes. The pseudogene-expressed IncRNA is one major type of IncRNA family. Small ubiquitin-like modifier (SUMO) 1 pseudogene 3, (SUMO1P3) is a novel indentified IncRNA that was previously reported to be up-regulated in gastric cancer. However, we know nothing about the biological function and underlying mechanism of SUMO1P3 in tumor. Furthermore, the relationship between SUMO1P3 and bladder cancer is completely unknown. We hypothesized that SUMO1P3 also have roles in bladder cancer.

In this study, we found that SUMO1P3 was significantly up-regulated in bladder cancer tissues compared with paired-adjacent nontumorous tissues in a cohort of 55 bladder cancer patients. Moreover, up-regulated SUMO1P3 expression was positively correlated with greater histological grade $(P<0.05)$ and advanced TNM stage $(P<0.05)$. Furthermore, we found cell proliferation / migration inhibition and apoptosis induction were also observed in SUMO1P3 siRNA-transfected bladder cancer cells. Our data suggest that SUMO1P3 plays oncogenic roles in bladder cancer and can be used as a potential prognostic and therapeutic target.

\section{INTRODUCTION}

Bladder cancer is the most common genitourinary tumors worldwide, and its incidence and mortality have been significantly increased in the past decades $[1,2]$. However, at the early stage of bladder cancer there are no specific symptoms for these patients [3]. Since the prognosis of bladder cancer is closely related to the stage of disease at diagnosis, novel diagnostic markers for early stage are urgently needed $[4,5]$. Despite improvements in surgery and adjuvant chemoradiotherapies, the 5-year survival rate for patients with bladder cancer remains at only $50-\mathrm{C} 60 \%[6,7]$.

The rapid development of RNA genomics has highlighted the role of long non-coding RNAs (lncRNAs) in many human diseases, especially in cancers [8-10]. Recent evidence showed that IncRNAs play important regulatory roles in diverse biological processes, such as 
transcriptional regulation, cell growth and tumorigenesis [11-14]. Examples include HOTAIR in breast cancer, MALAT1 in lung cancer and PCAT-1 in prostate cancer, indicating that lncRNAs play crucial roles in tumorigenesis or tumor progression [15-17]. Small ubiquitin-like modifier 1 pseudogene 3 (SUMO1P3) is a novel indentified long non-coding RNA that was originally identified as a potential prognostic and therapeutic target for gastric cancer [18]. However, the relationship between lncRNA SUMO1P3 and bladder cancer is completely unknown.

In the present study, we found that IncRNA SUMO1P3 was significantly up-regulated in bladder cancer tissues compared with paired-adjacent nontumorous tissues in a cohort of 55 bladder cancer patients. Further experiments indicated that silencing lncRNA SUMO1P3 could inhibit proliferation, induce apoptosis and suppress migration of the bladder cancer cell lines.

\section{RESULTS}

\section{SUMO1P3 was up-regulated in bladder cancer}

The relative expression level of SUMO1P3 was determined by using Real-Time qPCR in a total of 55 patients with urothelial bladder cancer and different cell lines. The SUMO1P3 expression fold change (bladder cancer tissue / matched normal tissue) in each patient was indicated in Figure 1A. As shown in Figure 1B, SUMO1P3 was up-regulated in bladder cancer tissues compared to pair-matched adjacent normal tissues. Moreover, up-regulated SUMO1P3 expression was positively correlated with greater histological grade (Figure 1C) and advanced TNM stage (Figure 1D). Furthermore, SUMO1P3 was up-regulated in bladder cancer cell lines (Figure 1E) compared to normal urothelial cell line. These results indicated that SUMO1P3 should play oncogenic roles in bladder cancer. Clinicopathological features of 55 patients and statistical results are shown in Table 1 and Table 2, respectively.

\section{Specific siRNA down-regulated expression of SUMO1P3}

Bladder cancer 5637, T24 and UM-UC-3 cells were cultured and transfected with SUMO1P3 siRNA or negative control siRNA. At 48 hours after transfection, the related expression level of SUMO1P3 was analyzed by qRT-PCR and the results of showed that the relative level of SUMO1P3 in 5637 (Figure 2A), T24 (Figure 2B) and UM-UC-3 (Figure 2C) cells was significantly down-regulated by the SUMO1P3 siRNA.

\section{Silencing SUMO1P3 inhibited cell proliferation}

We further determined whether SUMO1P3 promotes cell proliferation in bladder cancer. Bladder cancer 5637, T24 and UM-UC-3 cells were transfected with SUMO1P3 siRNA or negative control siRNA and the cell proliferation changes of bladder cells were determined using both CCK-8 assay and Edu assay. Cell growth arrest was observed in 5637 (Figure 3A, 3D and $3 \mathrm{G}$ ), T24 (Figure 3B, 3E and 3H) and UM-UC-3 (Figure $3 \mathrm{C}, 3 \mathrm{~F}$ and $3 \mathrm{I}$ ) cells as expected. These results confirmed that SUMO1P3 increases cell proliferation in bladder cancer.

\section{Silencing SUMO1P3 induced apoptosis}

We determined whether SUMO1P3 can inhibit cell apoptosis in bladder cancer. Bladder cancer 5637, T24 and UM-UC-3 cells were transfected with SUMO1P3 siRNA or negative control siRNA. The relative activity of caspase-3 was determined using ELISA assay (Figure $4 \mathrm{~A}, 4 \mathrm{~B}$ and $4 \mathrm{C}$ ). Furthermore, the apoptosis ratio in bladder cancer cells was measured using Hoechst 33342 staining and Flow cytometry. Induced cell apoptosis was also observed in 5637 (Figure 4D, 4G and Figure 5A, 5D), T24 (Figure 4E, 4H and Figure 5B, 5E) and UM-UC-3 (Figure 4F, 4I and Figure 5C, 5F) cells. These results demonstrated that SUMO1P3 suppresses cell apoptosis in bladder cancer.

\section{Silencing SUMO1P3 inhibited cell migration}

Finally, we determined whether SUMO1P3 promotes cell migration in bladder cancer. Bladder cancer 5637, T24 and UM-UC-3 cells were transfected with SUMO1P3 siRNA or negative control siRNA and the cell migration changes of bladder cells were determined by both wound healing assay and transwell assay. Cell migration arrest was observed in 5637 (Figure 6A, 6D and Figure 7A, 7D), T24 (Figure 6B, $6 \mathrm{E}$ and Figure $7 \mathrm{~B}, 7 \mathrm{E}$ ) and UM-UC-3 cells (Figure $6 \mathrm{C}, 6 \mathrm{~F}$ and Figure $7 \mathrm{C}, 7 \mathrm{~F}$ ) as expected. These results confirmed that SUMO1P3 increases cell migration in bladder cancer.

\section{DISCUSSION}

Bladder cancer is the most common genitourinary malignancies in human populations. The prognosis of bladder cancer remains quite poor, because most bladder cancers are found at advanced-stage when treatments are less effective $[19,20]$. Thus, finding new molecular targets for bladder cancer diagnosis, prognosis and treatment has the potential to improve 


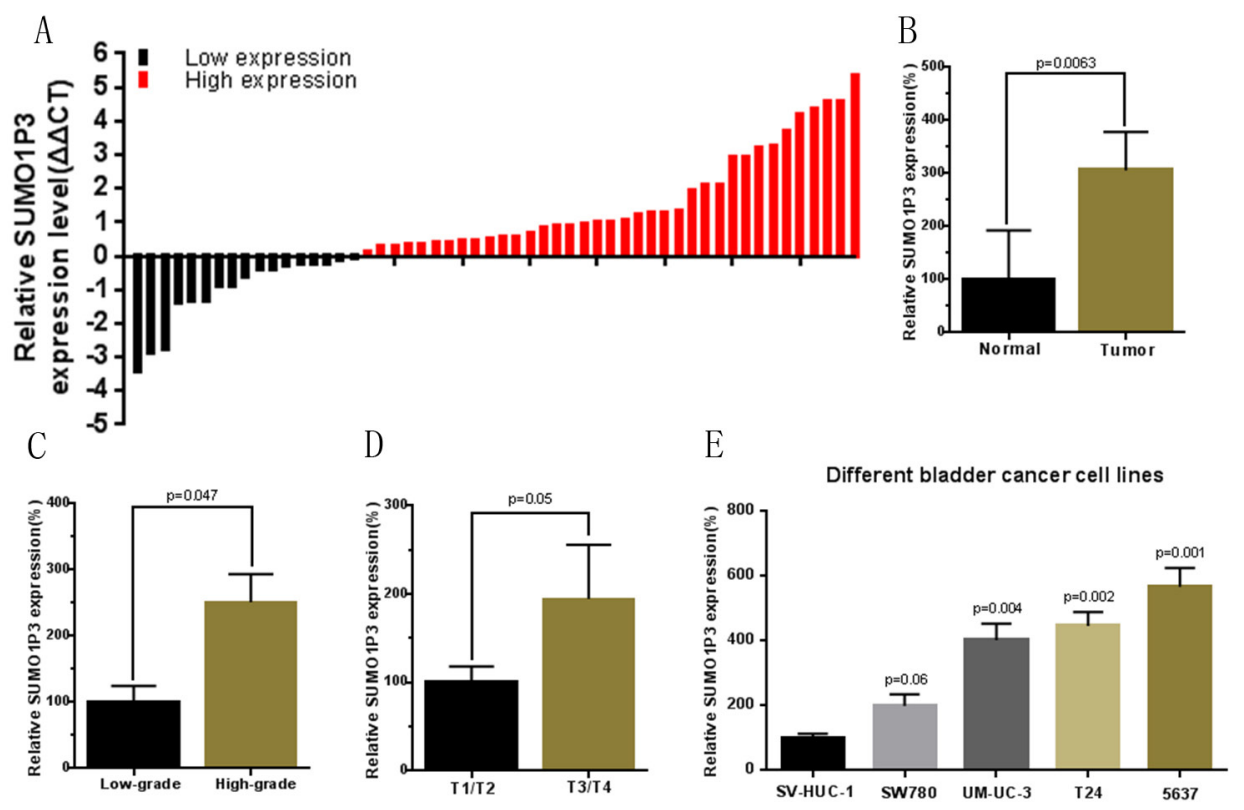

Figure 1: The long noncoding RNA SUMO1P3 was up-regulated in bladder cancer. The relative expression levels of SUMO1P3 were detected using Real-Time qPCR. A. SUMO1P3 expression levels were higher in bladder cancer tissues than those in normal bladder tissues. B. The relative expression level of SUMO1P3 was significantly higher in bladder cancer tissues compared with matched normal tissues. C. SUMO1P3 expression levels was significantly higher in patients with a higher pathological stage. D. SUMO1P3 expression levels were significantly higher in patients with higher TNM stage. E. SUMO1P3 expression levels were higher in bladder cancer cell lines than those in normal urothelial cell line. Data are shown as mean \pm SD.

Table 1: Correlation between SUMO1P3 expression and clinicopathological features of UCB patients

\begin{tabular}{|c|c|c|c|c|c|}
\hline \multirow[t]{2}{*}{ Parameters Total } & \multirow[t]{2}{*}{ Group } & \multirow[t]{2}{*}{ Total } & \multicolumn{2}{|l|}{$\begin{array}{l}\text { SUMO1P3 } \\
\text { expression }\end{array}$} & \multirow[t]{2}{*}{$P$ value } \\
\hline & & & High & Low & \\
\hline \multirow[t]{2}{*}{ Gender } & Male & $40(73 \%)$ & $28(51 \%)$ & $12(22 \%)$ & 0.528 \\
\hline & Female & $15(27 \%)$ & $10(18 \%)$ & $5(9 \%)$ & \\
\hline \multirow[t]{2}{*}{ Age (years) } & $<60$ & $20(36 \%)$ & $14(25 \%)$ & $6(11 \%)$ & 0.580 \\
\hline & $\geq 60$ & $35(64 \%)$ & $24(44 \%)$ & $11(20 \%)$ & \\
\hline \multirow[t]{2}{*}{ Tumor size (cm) } & $<3 \mathrm{~cm}$ & $21(38 \%)$ & $12(22 \%)$ & $9(16 \%)$ & 0.114 \\
\hline & $\geq 3 \mathrm{~cm}$ & $34(62 \%)$ & $26(47 \%)$ & $8(15 \%)$ & \\
\hline \multirow[t]{2}{*}{ Multiplicity } & Single & $33(60 \%)$ & $26(47 \%)$ & $7(13 \%)$ & 0.054 \\
\hline & Multiple & $22(40 \%)$ & $12(22 \%)$ & $10(18 \%)$ & \\
\hline \multirow[t]{2}{*}{ Histological grade } & Low(G1) & $23(42 \%)$ & $11(20 \%)$ & $12(22 \%)$ & 0.005 \\
\hline & $\operatorname{High}(\mathrm{G} 2, \mathrm{G} 3)$ & $32(58 \%)$ & $27(49 \%)$ & $5(9 \%)$ & \\
\hline \multirow[t]{2}{*}{ Tumor stage (T) } & $\mathrm{T} 1, \mathrm{~T} 2$ & $38(69 \%)$ & $23(42 \%)$ & $15(27 \%)$ & 0.037 \\
\hline & $\mathrm{T} 3, \mathrm{~T} 4$ & $17(31 \%)$ & $15(27 \%)$ & $2(4 \%)$ & \\
\hline \multirow[t]{2}{*}{$\begin{array}{l}\text { Lymph nodes metastasis } \\
\text { (N) }\end{array}$} & NO & $53(96 \%)$ & $27(49 \%)$ & $16(27 \%)$ & 0.618 \\
\hline & YES & $2(4 \%)$ & $1(2 \%)$ & $1(2 \%)$ & \\
\hline \multirow[t]{2}{*}{ Distal metastasis (M) } & M0 & $55(100 \%)$ & $38(69 \%)$ & $17(31 \%)$ & \\
\hline & M1 & 0 & 0 & 0 & \\
\hline
\end{tabular}


Table 2: Summary of clinicopathological features of tissues of bladder cancer

\begin{tabular}{|c|c|c|c|c|c|c|c|c|c|}
\hline Pt No. & Sex & Age & Stage & Grade & Pt No. & Sex & Age & Stage & Grade \\
\hline 1 & M & 66 & $\mathrm{~T} 2 \mathrm{bN} 0 \mathrm{M} 0$ & $\mathrm{H}$ & 29 & $\mathrm{M}$ & 63 & T2aN0M0 & $\mathrm{L}$ \\
\hline 2 & $\mathrm{~F}$ & 38 & T3aN0M0 & $\mathrm{H}$ & 30 & M & 58 & T4aN0M0 & $\mathrm{H}$ \\
\hline 3 & F & 64 & T1N0M0 & $\mathrm{L}$ & 31 & $\mathrm{M}$ & 50 & T2bN0M0 & $\mathrm{H}$ \\
\hline 4 & M & 75 & $\mathrm{~T} 2 \mathrm{bN} 0 \mathrm{M} 0$ & $\mathrm{H}$ & 32 & $\mathrm{M}$ & 59 & T4N0M0 & $\mathrm{H}$ \\
\hline 5 & M & 58 & T3aN0M0 & $\mathrm{H}$ & 33 & $\mathrm{~F}$ & 62 & T4aN0M0 & $\mathrm{H}$ \\
\hline 6 & M & 65 & T2bN0M0 & $\mathrm{H}$ & 34 & M & 41 & T1N0M0 & $\mathrm{L}$ \\
\hline 7 & M & 53 & T1N0M0 & $\mathrm{L}$ & 35 & M & 62 & T4aN0M0 & $\mathrm{H}$ \\
\hline 8 & M & 59 & T2bN0M0 & $\mathrm{H}$ & 36 & M & 76 & T2bN0M0 & L \\
\hline 9 & M & 43 & T3aN0M0 & $\mathrm{H}$ & 37 & M & 25 & T1N0M0 & L \\
\hline 10 & F & 64 & T2bN0M0 & $\mathrm{H}$ & 38 & F & 74 & T3aN0M0 & $\mathrm{H}$ \\
\hline 11 & M & 63 & T2bN0M0 & $\mathrm{H}$ & 39 & F & 70 & T1N0M0 & L \\
\hline 12 & M & 72 & T3aN0M0 & $\mathrm{H}$ & 40 & F & 72 & T1N0M0 & $\mathrm{L}$ \\
\hline 13 & M & 69 & T1N0M0 & L & 41 & M & 73 & T3bN0M0 & $\mathrm{H}$ \\
\hline 14 & M & 68 & T2bN0M0 & $\mathrm{H}$ & 42 & M & 63 & T3aN0M0 & $\mathrm{H}$ \\
\hline 15 & F & 63 & T3aN0M0 & $\mathrm{H}$ & 43 & M & 46 & T1N0M0 & $\mathrm{L}$ \\
\hline 16 & $\mathrm{~F}$ & 89 & T1N0M0 & $\mathrm{L}$ & 44 & M & 57 & T4aN0M0 & $\mathrm{H}$ \\
\hline 17 & M & 78 & T2aN0M0 & $\mathrm{L}$ & 45 & M & 70 & T2bN0M0 & $\mathrm{H}$ \\
\hline 18 & M & 70 & T2aN0M0 & $\mathrm{L}$ & 46 & M & 77 & T3aN0M0 & $\mathrm{H}$ \\
\hline 19 & $\mathrm{~F}$ & 41 & T2aN0M0 & $\mathrm{L}$ & 47 & M & 66 & T1N0M0 & L \\
\hline 20 & M & 59 & $\mathrm{~T} 2 \mathrm{bN} 0 \mathrm{M} 0$ & $\mathrm{H}$ & 48 & M & 53 & T2aN0M0 & L \\
\hline 21 & F & 73 & T2aN0M0 & $\mathrm{L}$ & 49 & M & 49 & T1N0M0 & L \\
\hline 22 & M & 67 & T2bN0M0 & $\mathrm{H}$ & 50 & M & 47 & T2aN0M0 & L \\
\hline 23 & F & 61 & T3aN0M0 & $\mathrm{H}$ & 51 & M & 68 & T1N0M0 & L \\
\hline 24 & M & 58 & T4aN3M0 & $\mathrm{H}$ & 52 & $\mathrm{M}$ & 61 & T3aN0M0 & $\mathrm{H}$ \\
\hline 25 & M & 63 & $\mathrm{~T} 2 \mathrm{aN} 0 \mathrm{M} 0$ & $\mathrm{~L}$ & 53 & F & 74 & T2bN0M0 & $\mathrm{H}$ \\
\hline 26 & $\mathrm{~F}$ & 51 & T1N0M0 & $\mathrm{L}$ & 54 & F & 60 & T2aN0M0 & $\mathrm{H}$ \\
\hline 27 & M & 86 & T1N0M0 & $\mathrm{L}$ & 55 & $\mathrm{M}$ & 73 & $\mathrm{~T} 2 \mathrm{bN} 1 \mathrm{M} 0$ & $\mathrm{H}$ \\
\hline 28 & M & 54 & T2bN0M0 & $\mathrm{H}$ & & & & & \\
\hline
\end{tabular}

A

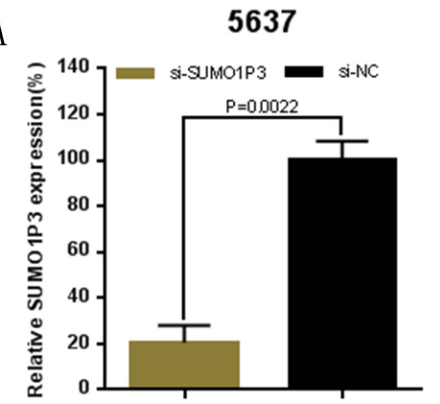

$\mathrm{B}$

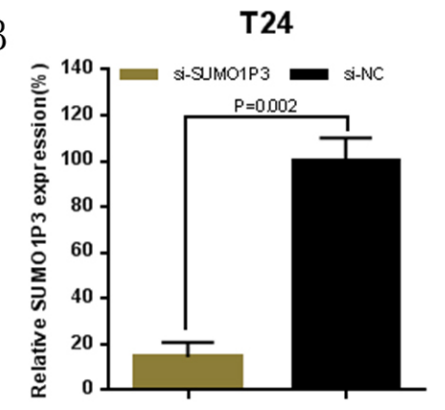

$\mathrm{C}$

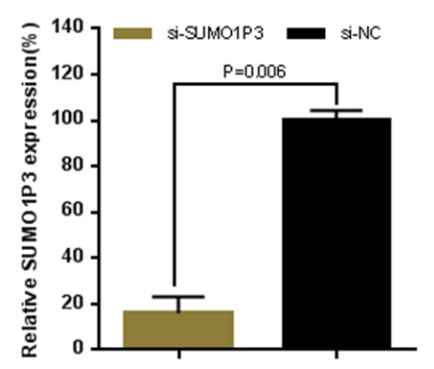

Figure 2: Expression changes of SUMO1P3 after transfection of SUMO1P3 specific siRNA or negative control siRNA. The relative expression level was determined using real-time qPCR. The SUMO1P3 specific siRNA significantly down-regulated the expression level of SUMO1P3 in 5637 A. T24 B. and UM-UC-3 C. cells. Data are shown as mean \pm SD. 
the clinical strategies and outcomes of bladder cancer $[21,22]$.

Long non-coding RNAs (lncRNAs) are a type of RNA molecule longer than 200 nucleotides and not translated into a protein [23, 24]. Recently, numerous pieces of evidence indicate that lncRNAs play a vital role in cancer progression and development [25, 26]. LncRNA SUMO1P3 was previously reported to be upregulated in gastric cancer. However, the relationship between IncRNA SUMO1P3 and bladder cancer is completely unknown. Furthermore, we know nothing about the biological function and underlying mechanism of lncRNA SUMO1P3 in cancers [27].

To the best of our knowledge, this is the first report of lncRNA SUMO1P3 being involved in the development of bladder cancer. In this study, we found that IncRNA SUMO1P3 was up-regulated in bladder cancer compared with paired-adjacent nontumorous tissue and up-regulated SUMO1P3 expression was positively correlated with greater histological grade and advanced TNM stage. These results suggest that lncRNA SUMO1P3 may emerge as a novel player
A

D

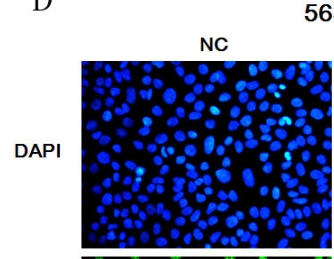

5637

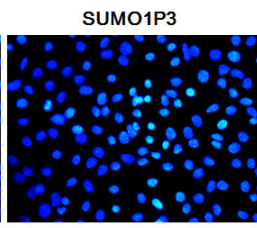

EdU
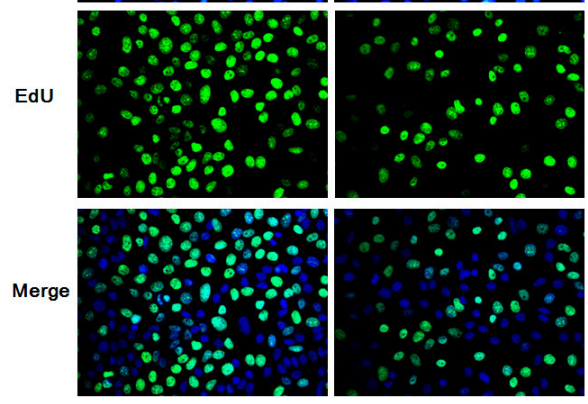

G

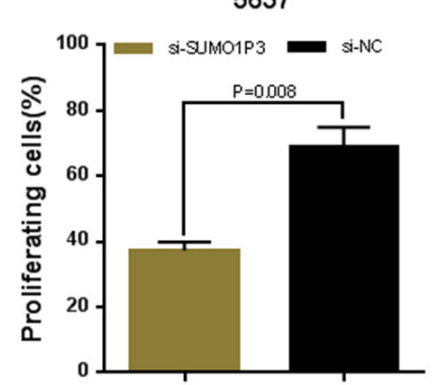

B

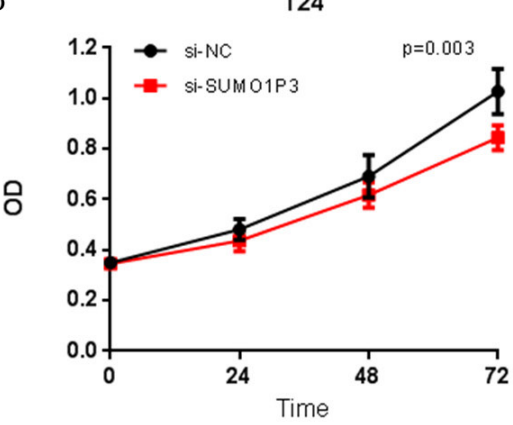

$\mathrm{E}$

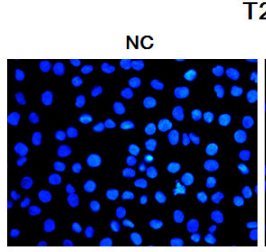

T24
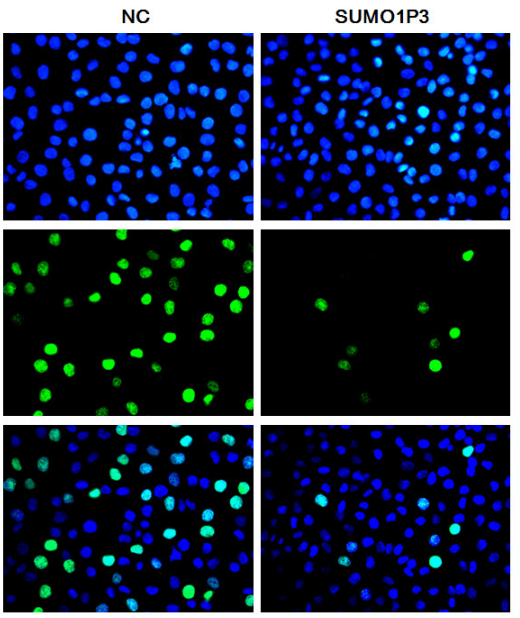

$\mathrm{H}$

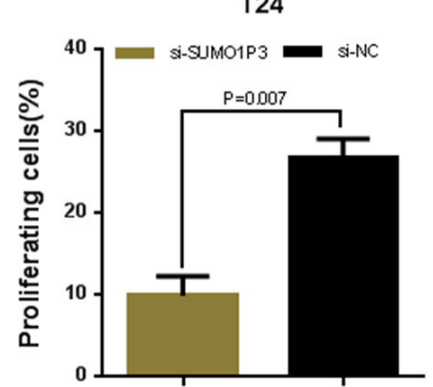

C

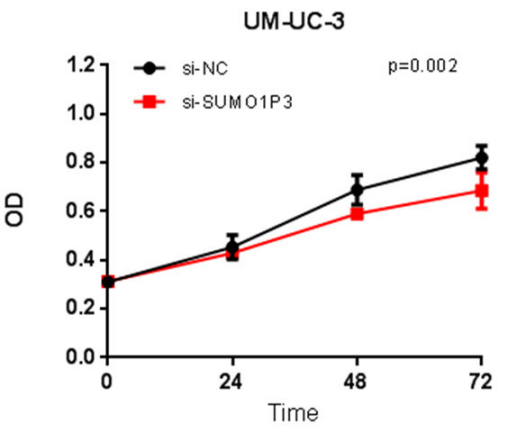

F
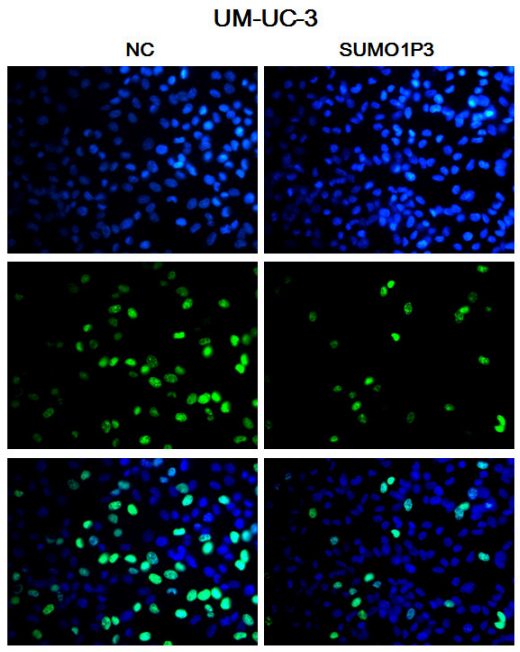

UM-UC-3

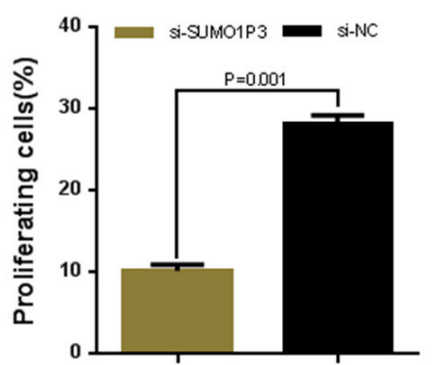

Figure 3: Silencing long noncoding RNA SUMO1P3 inhibited cell proliferation in bladder cancer cells. Cell proliferation was determined by both CCK-8 assay and Edu assay. Cell proliferation inhibition was observed in bladder cancer 5637 A, D. and G. T24 B, E. and H. and UM-UC-3 C, F. and I. cells. Data are shown as mean \pm SD. 
in the state of bladder cancer. In order to understand the biological functions of 1ncRNA SUMO1P3, we detected the cell proliferation, apoptosis and migration by silencing SUMO1P3 in the related bladder cancer cell lines. Inhibited proliferation, increased apoptosis and suppressed migration were observed in SUMO1P3 siRNA-transfected bladder cells. These findings indicated that SUMO1P3 may play key roles in the progression and development in bladder cancer.

In conclusion, the expression level of the lncRNA SUMO1P3 is increased in bladder cancer tissues compared with paired-adjacent nontumorous tissues. Upregulated SUMO1P3 expression has been associated with poor prognosis, likely due to the ability of SUMO1P3
A

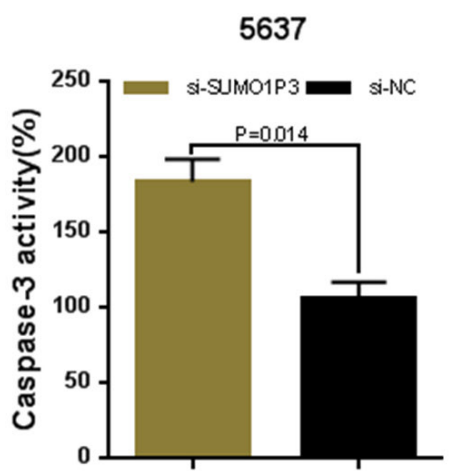

B

T24

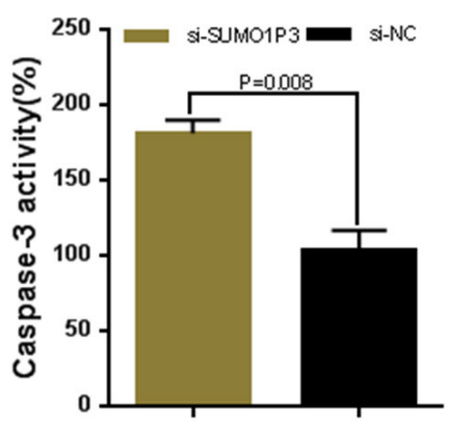

C

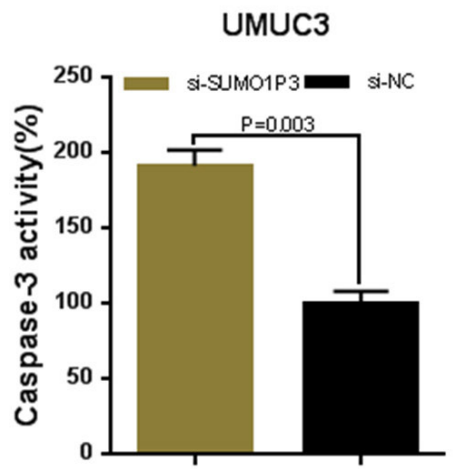

D
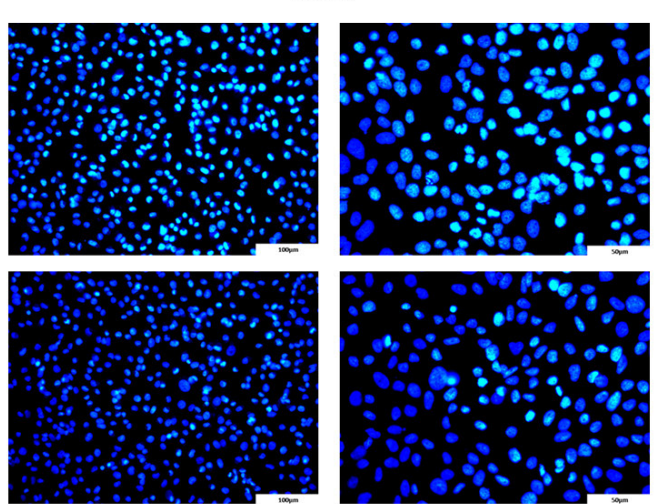

T24

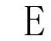

SUM01P3
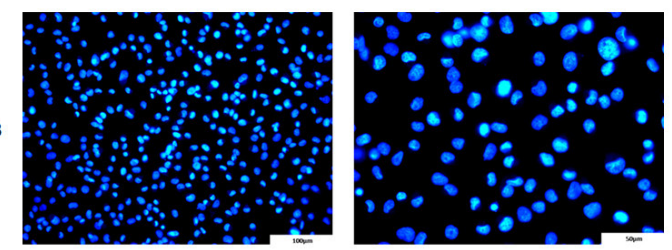

NC
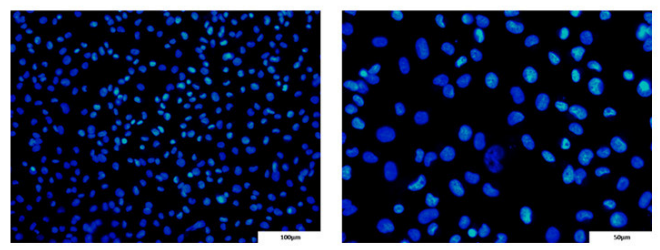

UMUC3
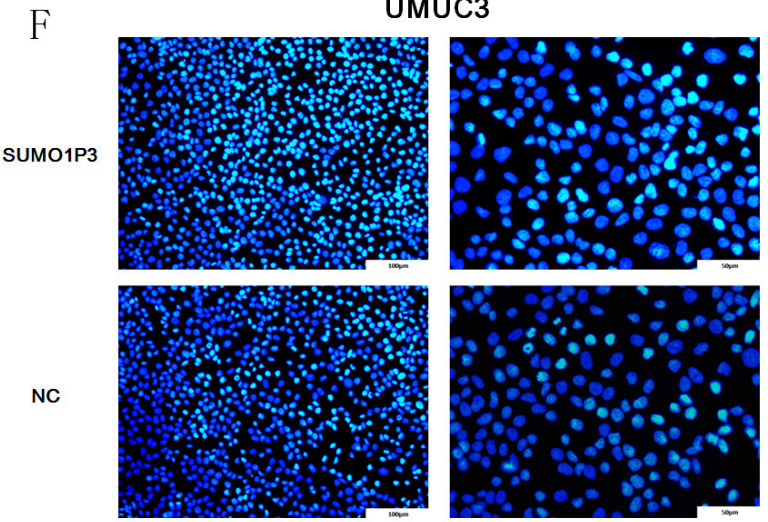

G

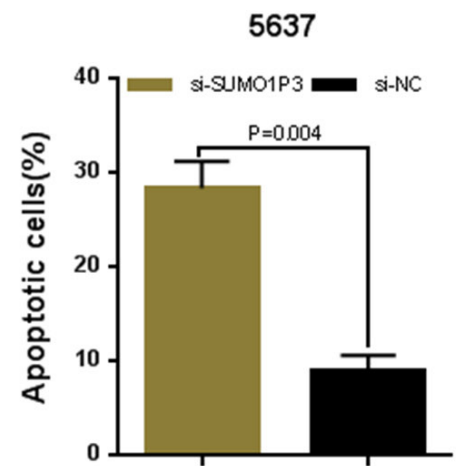

H

T24

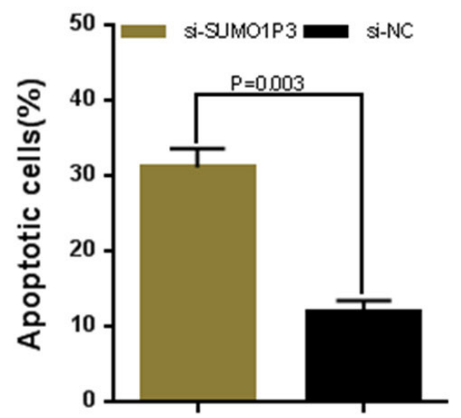

I
UMUC3

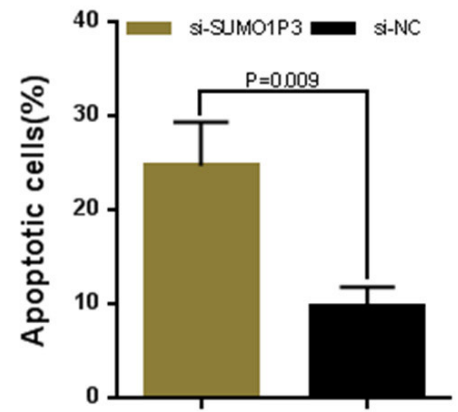

Figure 4: Silencing long noncoding RNA SUMO1P3 induced cell apoptosis in bladder cancer cells. Cell apoptosis was determined by both ELISA assay and Hoechst 33342 staining assay. Induced cell apoptosis was observed in bladder cancer 5637 A, D. and G. T24 B, E. and H. and UM-UC-3 C, F. and I. cells. Data are shown as mean \pm SD. 

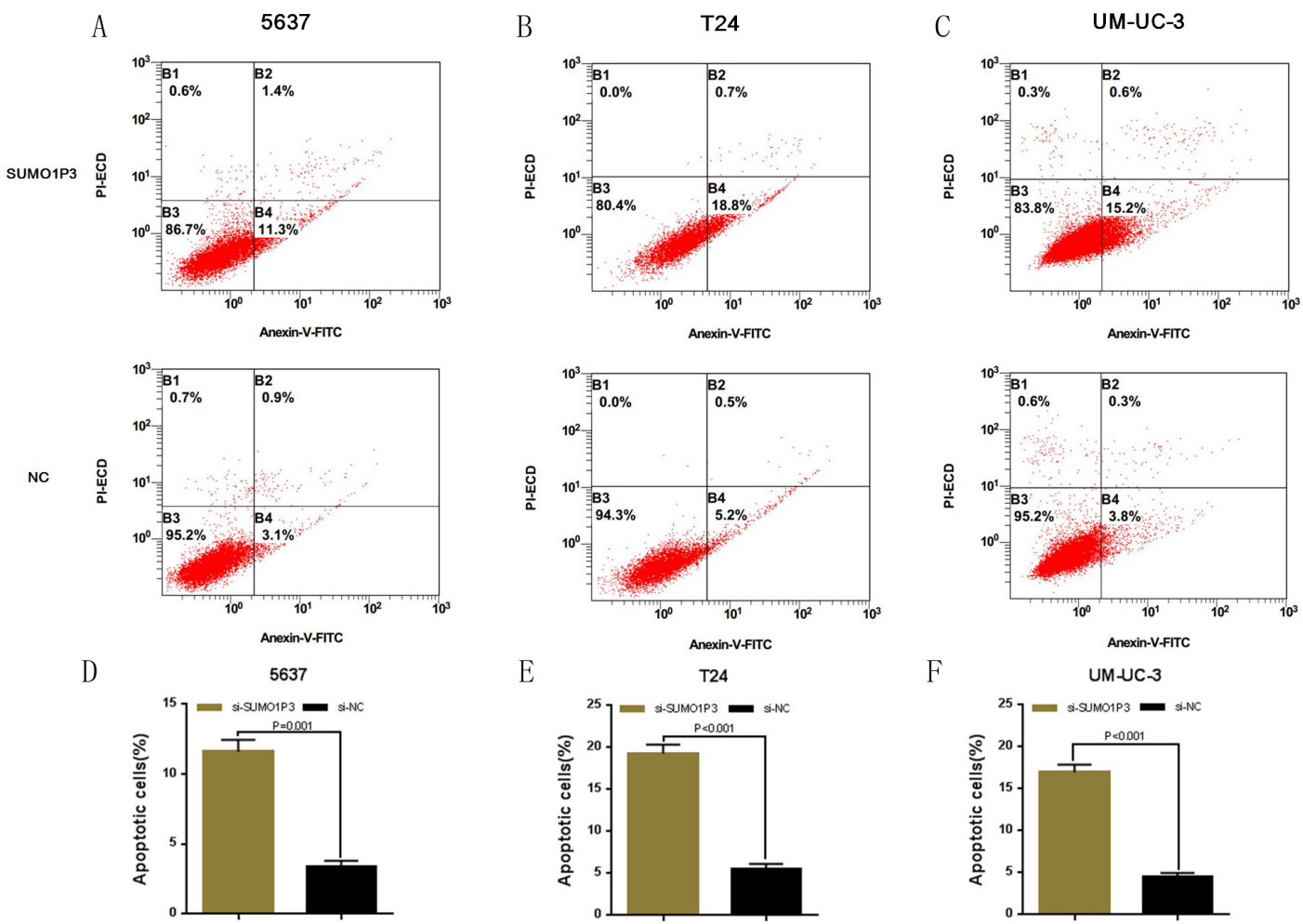

Figure 5: Silencing long noncoding RNA SUMO1P3 induced cell apoptosis in bladder cancer cells. Cell apoptosis was also determined by Flow cytometry. Induced cell apoptosis was observed in bladder cancer 5637 A. and D. T24 B. and E. and UM-UC-3 C. and F. cells. Data are shown as mean \pm SD.

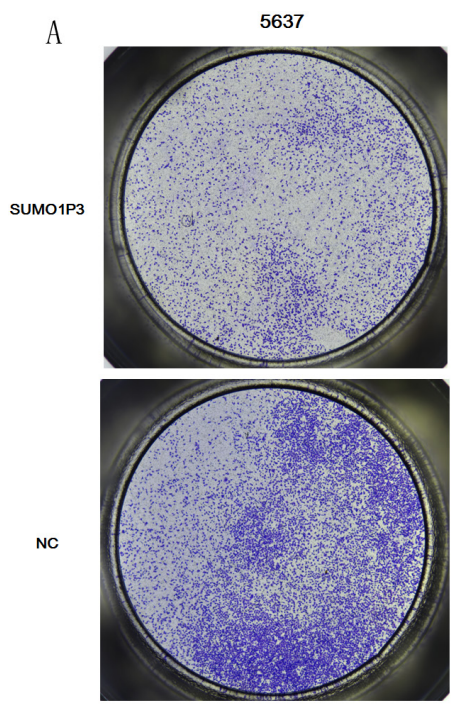

D

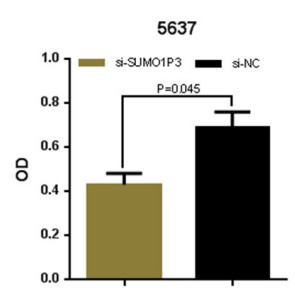

B
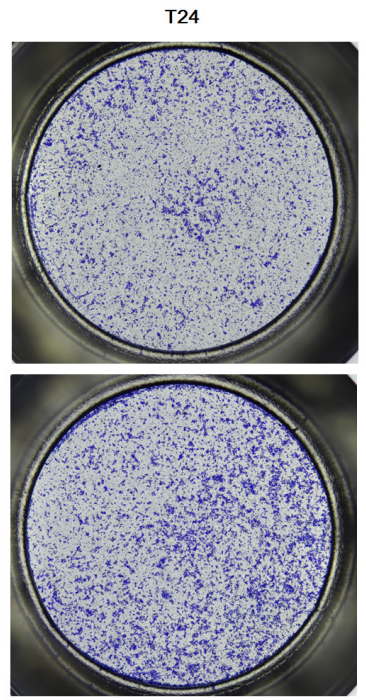

E

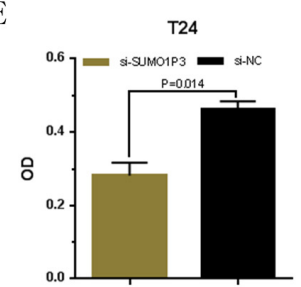

C
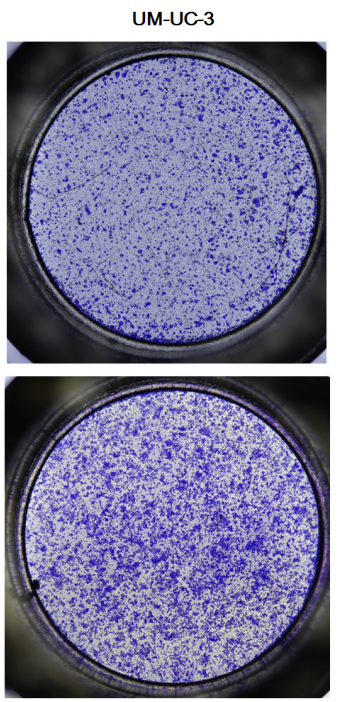

F

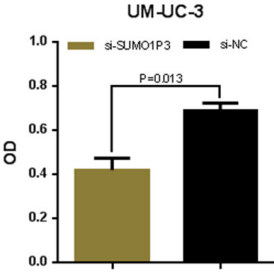

Figure 6: Silencing long noncoding RNA SUMO1P3 inhibited cell migration in bladder cancer cells. Cell migration was determined by both wound healing assay. Cell migration inhibition was observed in bladder cancer 5637 A. and D. T24 B. and E. and UMUC-3 C. and F. cells. Data are shown as mean \pm SD. 


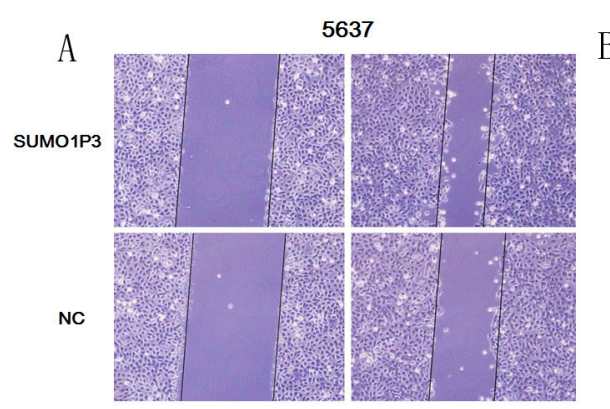

5637

D

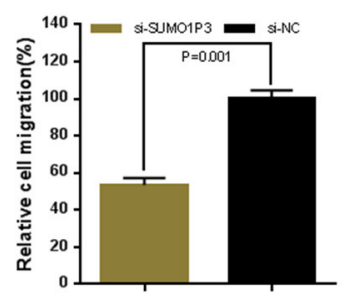

B

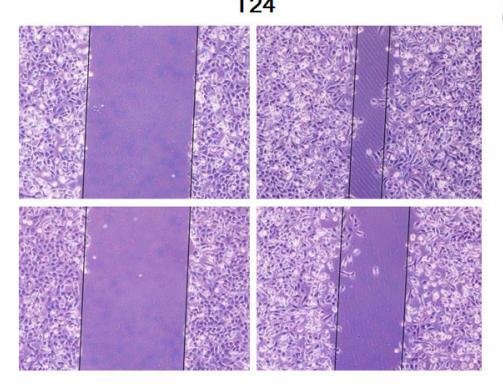

T24

$\mathrm{E}$

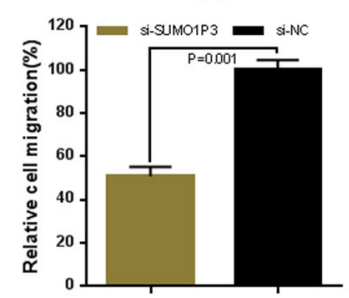

C

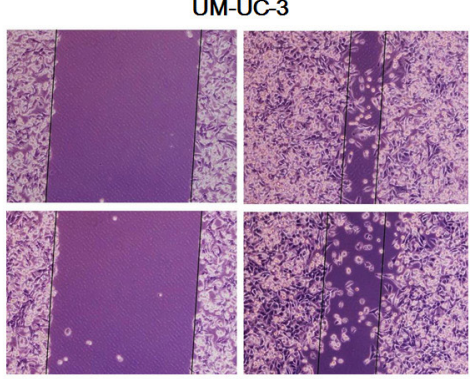

UM-UC-3

F

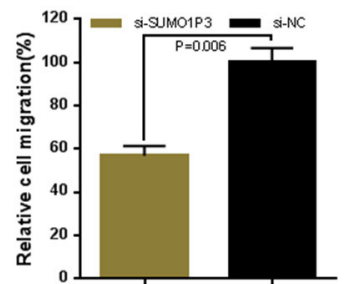

Figure 7: Silencing long noncoding RNA SUMO1P3 inhibited cell migration in bladder cancer cells. Cell migration was also determined by transwell assay. Cell migration inhibition was observed in bladder cancer 5637 A. and D. T24 B. and E. and UM-UC-3 C. and F. cells. Data are shown as mean \pm SD.

to induce cell growth and metastasis in bladder cancer cells. The molecular mechanism underlying SUMO1P3 upregulation in bladder cancer is still to be studied in future works.

Cumulatively, these findings indicate that SUMO1P3 play an oncogenic role in bladder cancer and SUMO1P3 may be used as a potential prognostic and therapeutic target of bladder cancer.

\section{MATERIALS AND METHODS}

\section{Patients and clinical samples collection}

A total of 55 urothelial bladder cancer tissues and their pair-matched adjacent normal tissues were obtained with informed consent from patients who underwent radical resections at Shenzhen Second People's Hospital, Shenzhen, China. This study was performed with the approval of the Research Ethics Committee of Shenzhen Second People's Hospital.

\section{Cell lines and cell culture}

Bladder cancer cells lines (5637, T24, UM-UC-3, SW780) and SV-40-immortalized human uroepithelial cell line (SV-HUC-1) used in this study were purchased from the Institute of Cell Research, Chinese Academy of Sciences, Shanghai, China. The T24, UM-UC-3 and SVHUC-1 cells were cultured in Dulbecco's Modified Eagle Medium (Invitrogen, Carlsbad, CA, USA) plus $10 \%$ fetal bovine serum. The 5637 and SW780 cells were cultured in RPMI-1640 Medium (Invitrogen, Carlsbad, CA, USA) plus $10 \%$ fetal bovine serum. Plates were then placed at $37{ }^{\circ} \mathrm{C}$ with a humidified atmosphere of $5 \% \mathrm{CO}_{2}$ in incubator.

\section{siRNA transfection}

Small interfering RNA that targeted SUMO1P3 and a scrambled negative control were purchased from GenePharma, Shanghai, China. The target sequence of siSUMO1P3 was 5'- TGGCCCTGATGTTCTAGCATGTGAT $-3^{\prime}$. The cells were cultured $24 \mathrm{~h}$ prior to transfection. Then, the cells were transiently transfected with either SUMO1P3 siRNA or negative control siRNA using Lipofectamine 2000 Transfection Reagent (Invitrogen, Carlsbad, CA, USA) according to the manufacturer's instructions. After $48 \mathrm{~h}$, cells transfected with siRNA were harvested for qRT-PCR .

\section{RNA extraction and quantitative real-time PCR}

The total RNA of the tissue samples or the transfected cells were extracted using the Trizol reagent (Invitrogen, Carlsbad, CA, USA) according to the manufacturer's protocol. The concentration and purity of the total RNA were detected with UV spectrophotometer analysis at $260 \mathrm{~nm}$ and the electrophoresis detection showed good quality of purified RNA. cDNA was converted from total RNA by using SuperScript III (Invitrogen) according to the instructions. The primer sequences were as follows: SUMO1P3 primers $^{8}$ forward: 5'- ACTGGGAATGGAGGAAGA -3', reverse: 5'TGAGAAAGGATTGAGGGAAAAG -3'; GAPDH primers forward: 5'- CGCTCTCTGCTCCTCCTGTTC -3', reverse: 5'- ATCCGTTGACTCCGACCTTCAC -3'. Quantitative real-time PCR was performed by using the ABI PRISM 7000 
Fluorescent Quantitative PCR System (Applied Biosystems, Foster City, CA, USA) according to the manufacturer's instructions. The average value in each triplicate was used to calculate the relative amount of SUMO1P3 using $2-\Delta \Delta \mathrm{Ct}$ methods. Experiments were repeated at least three times.

\section{Cell counting Kit-8 assay}

Cell proliferation was determined using Cell Counting Kit-8 (Beyotime Inst Biotech, China) according to instructions. Briefly, $5 \times 10^{3}$ cells/well were seeded in a 96-well flat-bottomed plate for $24 \mathrm{~h}$, then transfected with si-SUMO1P3 or si-NC and cultured in normal medium. At $0,24,48$ and $72 \mathrm{~h}$ after transfection, $10 \mu \mathrm{l}$ of CCK-8 $(5 \mathrm{mg} / \mathrm{ml})$ was added to each well and the cells were cultured for 1 hour [28]. The absorbance in each well was finally determined at a wavelength of $450 \mathrm{~nm}$ using a microplate reader (BioRad, Hercules, CA, USA). Experiments were repeated at least three times.

\section{Ethynyl-2-deoxyuridine (EdU) incorporation assay}

Cell proliferation was also determined by Ethynyl2-deoxyuridine incorporation assay using an EdU Apollo DNA in vitro kit (RIBOBIO, Guangzhou, China) following the manufacturer's instructions. Briefly, $5 \times 10^{3}$ cells $/$ well was seeded in a 96-well plate for $24 \mathrm{~h}$, then transfected with si-SUMO1P3 or si-NC. At $48 \mathrm{~h}$ after transfection, cells were incubated with $100 \mu \mathrm{l}$ of $50 \mu \mathrm{M} \mathrm{EdU}$ per well for $2 \mathrm{~h}$ at $37^{\circ} \mathrm{C}$. Then, the cells were fixed for $30 \mathrm{~min}$ at room temperature using $100 \mu \mathrm{l}$ of fixing buffer (4\% polyformaldehyde containing PBS). Subsequently, the cells were incubated with $50 \mu \mathrm{l}$ of $2 \mathrm{mg} / \mathrm{ml}$ glycine for $5 \mathrm{~min}$ followed by washing with $100 \mu 1$ of PBS. After permeabilization with $0.5 \%$ TritonX, the cells were reacted with 1X Apollo solution for $30 \mathrm{~min}$ at room temperature in the dark. After that, cells were incubated with $100 \mu \mathrm{l}$ of $1 \mathrm{X}$ Hoechst 33342 solution for $30 \mathrm{~min}$ at room temperature in the dark followed by washing with $100 \mu \mathrm{l}$ of PBS [29]. The cells were then visualized under a fluorescence microscopy. Experiments were repeated at least three times.

\section{Caspase-3 ELISA assay}

Cell apoptosis was determined by ELISA assay. Cell Caspase-3 activity was measured using the Caspase-3 Colorimetric Assay kit (Abcam, Cambridge, UK) according to the manufacturer's protocol at 48 hours after transfection, respectively[29]. Experiments were repeated at least three times in duplicates.

\section{Hoechst 33342 staining assay}

Apoptotic cells induced by SUMO1P3 silencing were also observed by using the Hoechst 33258 staining kit (Life, Eugene, OR, USA) according to the manufacturer's instructions. Briefly, $5 \times 10^{4}$ cells/well was seeded in a 12-well plate for $24 \mathrm{~h}$, then transfected with siRNA. At $48 \mathrm{~h}$ after transfection, the cells were fixed for $30 \mathrm{~min}$ at room temperature using $100 \mu \mathrm{l}$ of fixing buffer (4\% polyformaldehyde containing PBS). Subsequently, cells were incubated with $100 \mu 1$ of $1 \mathrm{X}$ Hoechst 33342 solution for $30 \mathrm{~min}$ at room temperature in the dark followed by washing with $100 \mu \mathrm{l}$ of PBS [30]. The cells were then visualized under a fluorescence microscopy. Experiments were repeated at least three times.

\section{Flow cytometry assay}

Cell apoptosis was also determined by flow cytometry. After $48 \mathrm{~h}$, cells transfected with siRNA were harvested for flow cytometry assay. After double staining with FITC-Annexin V and PI according to the manufacturer's instructions, cell apoptosis was determined by using flow cytometry (EPICS, XL-4, Beckman, CA, USA), respectively. Experiments were repeated at least three times in duplicates [31].

\section{Wound healing assay}

Cell motility was determined by wound healing assay. At $24 \mathrm{~h}$ post transfection, a wound field was created using a sterile $200 \mu \mathrm{l}$ pipette tip in about $90 \%$ confluent cells. The cells were incubated for $24 \mathrm{~h}$ at $37^{\circ} \mathrm{C}$, and then the migration of cells was monitored with a digital camera system. The cell migration distance $(\mu \mathrm{m})$ was calculated by the software program HMIAS-2000 [32]. Experiments were repeated at least three times.

\section{Transwell assay}

The cell motility assay were also performed using a transwell insert ( $8 \mu \mathrm{m}$, Corning). $24 \mathrm{~h}$ after transfection, $5 \times 104$ cells were first starved in $200 \mathrm{ml}$ serumfree medium and then placed in the uncoated dishes [33]. The lower chamber was filled with $500 \mathrm{ml}$ of complete medium. The cells were incubated for $48 \mathrm{~h}$ at $37^{\circ} \mathrm{C}$, and then the cells that had migrated to the bottom surface of the filter membrane were stained with $0.5 \%$ crystal violet solution and photographed in five preset fields per insert. The results represented the average of three independent experiments.

\section{Statistical analyses}

All experimental data from three independent experiments were analyzed by Student's t-test or ANOVA and results were expressed as mean $\pm \mathrm{SD}$. P-values of less than 0.05 were considered to be statistically significant. All statistical tests were conducted by SPSS version 19.0 software (SPSS Inc.Chicago, IL, USA). 


\section{ACKNOWLEDGMENTS}

The authors are appreciative to the donors, whose names were not included in the author list, but who participated in this program. This work was funded by the National Key Basic Research Program of China (973 Program) (2014CB745201), the Chinese High-Tech (863) Program (2014AA020607), National Natural Science Foundation of China [81402103], International S\&T Cooperation program of China (ISTCP) (2014DFA31050), The National Science Foundation Projects of Guangdong Province (2014A030313717), the Shenzhen Municipal Government of China (ZDSYS201504301722174, JCYJ20150330102720130, GJHZ20150316154912494), and Special Support Funds of Shenzhen for Introduced High-Level Medical Team.

\section{CONFLICTS OF INTEREST}

The authors declare that they have no conflict of interest with this study.

\section{REFERENCES}

1. Burger M, Catto JWF, Dalbagni G. Epidemiology and risk factors of urothelial bladder cancer. European urology. 2013; 63: 234-241.

2. Witjes JA, Compérat E, Cowan NC, De Santis M, Gakis G, Lebret T, Ribal MJ, Van der Heijden AG, Sherif A. EAU guidelines on muscle-invasive and metastatic bladder cancer: summary of the 2013 guidelines. European urology. 2014; 65: 778-792.

3. Jin X, Yun SJ, Jeong P, Kim IY, Kim WJ, Park S. Diagnosis of bladder cancer and prediction of survival by urinary metabolomics. Oncotarget. 2014; 5: 1635. doi: 10.18632/ oncotarget. 1744

4. Cheng L, Davison DD, Adams J, Lopez-Beltran A, Wang L, Montironi R, Zhang S. Biomarkers in bladder cancer: translational and clinical implications. Critical reviews in oncology/hematology. 2014; 89: 73-111.

5. Kim WJ, Bae SC. Molecular biomarkers in urothelial bladder cancer. Cancer science. 2008; 99: 646-652.

6. Chester JD, Hall GD, Forster M, Protheroe AS. Systemic chemotherapy for patients with bladder cancer-current controversies and future directions. Cancer treatment reviews. 2004; 30: 343-358.

7. Budman LI, Kassouf W, Steinberg JR. Biomarkers for detection and surveillance of bladder cancer. Canadian Urological Association Journal. 2008; 2: 212.

8. Powe DG, Voss MJ, Zänker KS, Habashy HO, Green AR, Ellis IO, Entschladen F. Beta-blocker drug therapy reduces secondary cancer formation in breast cancer and improves cancer specific survival. Oncotarget. 2010; 1: 628. doi: 10.18632/oncotarget.197
9. Liu Y, Han Y, Huang W, Cai Z. Whole-genome synthesis and characterization of viable S13-like bacteriophages. PloS one. 2012; 7: e41124.

10. Mercer TR, Dinger ME, Mattick JS. Long non-coding RNAs: insights into functions. Nature Reviews Genetics. 2009; 10: 155-159.

11. Spizzo R, Almeida MI, Colombatti A. Long non-coding RNAs and cancer: a new frontier of translational research\&quest. Oncogene. 2012; 31: 4577-4587.

12. Gibb EA, Brown CJ, Lam WL. The functional role of long non-coding RNA in human carcinomas. Mol Cancer. 2011; 10: 38-55.

13. Liu Y, Zeng Y, Liu L, Cai Z. Synthesizing AND gate genetic circuits based on CRISPR-Cas9 for identification of bladder cancer cells. Nature communications. 2014; 5 .

14. Smalley DM, Sheman NE, Nelson K, Theodorescu D. Isolation and identification of potential urinary microparticle biomarkers of bladder cancer. Journal of proteome research. 2008; 7: 2088-2096.

15. Gupta RA, Shah N, Wang KC, Kim J, Horlings HM, Wong DJ, Tsai MC, Hung T, Argani P, Rinn JL, Wang Y, Brzoska $\mathrm{P}$, Kong B, et al. Long non-coding RNA HOTAIR reprograms chromatin state to promote cancer metastasis. Nature. 2010; 464: 1071-1076.

16. Gutschner T, Hämmerle M, Eißmann M, Hsu J, Kim Y, Hung G, Revenko A, Arun G, Stentrup M, Gross M, Zörnig M, MacLeod AR, Spector DL, et al. The noncoding RNA MALAT1 is a critical regulator of the metastasis phenotype of lung cancer cells. Cancer research. 2013; 73: 1180-1189.

17. Prensner JR, Iyer MK, Balbin OA, Dhanasekaran SM, Cao Q, Brenner JC, Laxman B, Asangani IA, Grasso CS, Kominsky HD, Cao X, Jing X, Wang X, et al. Transcriptome sequencing across a prostate cancer cohort identifies PCAT-1, an unannotated lincRNA implicated in disease progression. Nature biotechnology. 2011; 29: 742-749.

18. Mei D, Song H, Wang K, Lou Y, Sun W, Liu Z, Ding $\mathrm{X}$, Guo J. Up-regulation of SUMO1 pseudogene 3 (SUMO1P3) in gastric cancer and its clinical association. Medical Oncology. 2013; 30: 1-5.

19. Kirkali Z, Chan T, Manoharan M, Algaba F, Busch C, Cheng L. Bladder cancer: epidemiology, staging and grading, and diagnosis. Urology. 2005; 66: 4-34.

20. Lewis JD, Ferrara A, Peng T, Hedderson M, Bilker WB, Quesenberry CP Jr, Vaughn DJ, Nessel L, Selby J, Strom BL. Risk of bladder cancer among diabetic patients treated with pioglitazone interim report of a longitudinal cohort study. Diabetes care. 2011; 34: 916-922.

21. Neumann A, Weill A, Ricordeau P, Fagot JP, Alla $\mathrm{F}$, Allemand H. Pioglitazone and risk of bladder cancer among diabetic patients in France: a population-based cohort study. Diabetologia. 2012; 55: 1953-1962.

22. Zhan Y, Liu Y, Lin J, Fu X, Zhuang C, Liu L, Xu W, Li J, Chen M, Zhao G, Huang W, Cai Z. Synthetic 
Tet-inducible artificial microRNAs targeting $\beta$-catenin or HIF-1 $\alpha$ inhibit malignant phenotypes of bladder cancer cells T24 and 5637. Scientific reports. 2015; 5.

23. Wapinski O, Chang HY. Long noncoding RNAs and human disease. Trends in cell biology. 2011; 21: 354-361.

24. Wang KC, Yang YW, Liu B, Sanyal A, Corces-Zimmerman R, Chen Y, Lajoie BR, Protacio A, Flynn RA, Gupta RA, Wysocka J, Lei M, Dekker J, et al. A long noncoding RNA maintains active chromatin to coordinate homeotic gene expression. Nature. 2011; 472: 120-124.

25. Li H, Yu B, Li J, Su L, Yan M, Zhu Z, Liu B. Overexpression of lncRNA H19 enhances carcinogenesis and metastasis of gastric cancer. Oncotarget. 2014; 5: 2318. doi: 10.18632/oncotarget.1913

26. Qi P, Du X. The long non-coding RNAs, a new cancer diagnostic and therapeutic gold mine. Modern Pathology. 2013; 26: $155-165$.

27. Song H, Sun W, Ye G, Ding X, Liu Z, Zhang S, Xia T, Xiao $\mathrm{B}, \mathrm{Xi}$ Y, Guo J. Long non-coding RNA expression profile in human gastric cancer and its clinical significances. J Transl Med. 2013; 11: 225.

28. Lin J, Liu Y, Zhan Y, Zhuang C, Liu L, Fu X, Xu W, Li J, Chen M, Cai Z, Huang W. Synthetic Tet-inducible small hairpin RNAs targeting hTERT or Bcl-2 inhibit malignant phenotypes of bladder cancer T24 and 5637 cells. Tumour biology. 2015.
29. Chehrehasa F, Meedeniya AC, Dwyer P, Abrahamsen G, Mackay-Sim A. EdU, a new thymidine analogue for labelling proliferating cells in the nervous system. J Neurosci Methods. 2009; 177:122-130.

30. Rodenas C, Lucas X, Tarantini T, Del Olmo D, Roca J, Vazquez JM, Martinez EA, Parrilla I. The effects of hoechst 33342 staining and the male sample donor on the sorting efficiency of canine spermatozoa. Reproduction in domestic animals. 2014; 49: 115-121.

31. Darzynkiewicz Z, Zhao H. Cell cycle analysis by flow cytometry. eLS. 2014. doi: 10.1002/9780470015902. a0002571.pub2.

32. Liu L, Liu Y, Zhuang C, Xu W, Fu X, Lv Z, Wu H, Mou L, Zhao G, Cai Z, Huang W. Inducing cell growth arrest and apoptosis by silencing long non-coding RNA PCAT-1 in human bladder cancer. Tumor Biology. 2015; 36:7685-9. doi: 10.1007/s13277-015-3490-3.

33. 33.Primiceri E, Chiriacò MS, Dioguardi F, Monteduro AG, D’Amone E, Rinaldi R, Giannelli G, Maruccio G. Automatic transwell assay by an EIS cell chip to monitor cell migration. Lab on a Chip. 2011; 11: 4081-4086. Primiceri E, Chiriacò MS, Dioguardi F, Monteduro AG, D’Amone E, Rinaldi R, Giannelli G, Maruccio G. Automatic transwell assay by an EIS cell chip to monitor cell migration. Lab on a Chip, 2011, 11: 4081-4086. 